\title{
GEOLOGY
}

DOI https://doi.org/10.30525/978-9934-26-111-4-42

\section{ОСНОВНІ РИСИ КАРБОНОВИХ ВУГЛЕНОСНИХ ФОРМАЦІЙ НА МЕЖІ ЛЬВІВСЬКО-ВОЛИНСЬКОГО І ЛЮБЛІНСЬКОГО КАМ'ЯНОВУГІЛЬНИХ БАСЕЙНІВ}

\author{
Матрофайло М. М. \\ кандидат геолого-мінералогічних наук, \\ старший науковий співробітник, \\ старший науковий співробітник відділу геології і геохімї̈ \\ твердих горючих копалин \\ Інститут геологї і геохімї̈ горючих копалин \\ Начіональної академії наук Украӥни
}

Бучинська I. В.

кандидат геологічних наук, старший науковий співробітник, стариий науковий співробітник відділу геологї̈ і геохімї̈ твердих горючих копалин

Інститут геологї і геохімї̈ горючих копалин

Національної академії наук Украӥни

м. Львів, Україна

Вугленосна мегаформація кам'яновугільного Львівсько-Люблінського басейну (ЛЛБ) поширена в межах однойменного перикратонного прогину північно-західного простягання, розташованого на південнозахідній окраїни Східноєвропейської платформи на стику іiі з молодою Західно-Свропейською платформою $[1,2]$. У південно-східній частині прогину розташований Львівсько-Волинський кам'яновугільний басейн (ЛВБ). На прикордонній території ЛВБ вугленосні відклади належать до верхнього візе-башкирського ярусу (верхній візе-вестфал А). Відклади карбонової мегаформації ЛЛБ залягають 3 кутовою i стратиграфічною незгідністю на еродованій гетерогенній поверхні потужних утворень верхнього протерозою, кембрію, ордовику, силуру, верхнього девону, що зумовило її особливий неповторний розвиток.

Підошва відкладів карбону в межах прикордонної частини ЛЛБ розташована на абсолютних відмітках від 139 м поблизу скиду Удальу до 2000 м в районі синкліналі Ізбіцу, яка відповідає Карівскій і Тяглівській синкліналям ЛВБ. Поверхня карбону (як і підошва) 
нахилена на південний захід під кутом $1-2^{\circ}$, а іiі абсолютні значення змінюються від 0 м на крайньому північному сході території до 1000 м на південному заході.

Сучасна поверхня відкладів карбону є ерозійною. Між Влодавою, Любомлем і Дубієнкою, а також в південно-західній частині ЛВБ кам'яновугільні відклади покриваються утвореннями верхньої юри. На решта частини ЛВБ, а також в межах прикордонної території України i Польщі на карбоні безпосередньо залягають глауконітові пісковики і карбонатні відклади верхньої крейди. Північне продовження ЛВБ розташоване в межах Ковельського тектонічного виступу, який $\epsilon$ частиною Ковельсько-Хрубешувського поперечного підняття [3].

Для ЛВБ і прикордонної території ЛБ характерно широкий розвиток диз'юнктивних порушень. Моноклінальне падіння ускладнене чергуванням синклінальних (Польська частина: Кумова, КросниставГрабовецька, Тягловська, Каровська; Українська: Сокальська, Межирічанська, Тяглівська, Карівська) і антиклінальних зон (Польська частина: Великих-Мостув, Бутинська, Комарова; Українська: БелзМилятинська, Бутинь-Хлівчанська, Нестерівська зони насувів) північно-західного простягання, в межах яких кути падіння порід досягають 6-8 $8^{\circ}$ [1]. Структури стають пологими в південно-східному напрямку.

Переважають розривні дислокації північно-західного простягання. Поперечні (північно-східні) порушення менш поширені. Південнозахідна частина території, в порівнянні з північно-східною, характеризується більш інтенсивною тектонічною порушенісьтю. У іiі межах розташовано найбільший Рава-Руський розлом 3 амплітудою до 2000-3000 м [4], який простягається у напрямку Замосць і $\epsilon$ південно-західним кордоном поширення відкладів карбону. Другий важливий розлом - Володимир-Волинський (Північний) 3 амплітудою до 1000 м - розташований на півночі Нововолинського геолого-промислового району і має широтне простягання. Крім крупних тектонічних порушень, дуже поширені також дрібноамплітудні (скиди, підкиди), більшість 3 яких виявляється лиш гірськими виробками шахт $[5,6]$.

Українська частина ЛЛБ характеризується високим ступенем розвіданості і промислового освоєння вугільних родовищ. У iї межах виділяються два геолого-промислових райони: Нововолинський (Нововолинське родовище) і Червоноградський (Забузьке, Сокальське i Межирічанське родовища), а також Південно-Західний вугленосний район (Тяглівське і Любельське родовища) та Ковельська вугленосна площа.

Потужність вугленосної формації на прикордонній території ЛЛБ зростає в південно-західному напрямку від 5-10 м на Ковельській 
вугленосної площі до 1500 м на заході Південно-Західного району ЛВБ. Загальний план зміни потужностей характерний також і для окремих підформацій.

Вугленосні формації ЛВБ і ЛБ складаються переважно теригенними породами - алевролітами і пісковиками, широко розвинуті аргіліти. Вапняки і вугілля мають підпорядковане поширення. Вкрай обмеженим розвитком характеризуються конгломерати і гравеліти. Для обох вугленосних формацій характерне збільшення угору по розрізу пісковиків, алевролітів і вугілля. Значні зміни літологічного складу формацій відбуваються і в латеральному напрямку. Зі сходу на захід у вугленосних формаціях, а також в окремих підформаціях відбувається зменшення поширення пісковиків, алевролітів, а вміст аргілітів і вапняків збільшується.

Літогенетичний опис розрізів карбону на прикордонній території України і Польщі показав велику схожість вертикальної зміни літологофаціального складу вугленосних формацій ЛВБ і ЛБ. У латеральному напрямку також встановлені значні зміни. 3 північного сходу на південний захід до центральної частини Львівсько-Люблінського прогину у розрізі формації і окремих підформацій спостерігається зменшення континентальних i збільшення перехідних i морських відкладів. Скорочується розвиток фацій піщаних і алевритових осадів усть і низин річок, вуглистих осадів торф'яних боліт і сапропелевих озер i, навпаки, збільшується поширення фацій глинистих і карбонатних осадів моря. Цим, зокрема, пояснюється більший розвиток $\mathrm{i}$ більш різноманітний систематичний склад гониатитів вугленосної формації ЛБ, у порівнянні з ЛВБ [1].

У вугленосній мегаформаціі ЛЛБ вугільні пласти і прошарки залягають у відкладах від верхнього візи до московського ярусу середнього карбону (вестфал C, D?). Потужність вугільних пластів змінюється від 0,05 до 4 м. Промислові пласти вугілля на території Польщі містяться у формаціях Теребіна і Дебліна (нижня і верхня вугленосні підформаціі ЛВБ), а також Любліна. Запаси вугілля (категорії А-С2) розвідані в центральній частині ЛБ у відкладах московського ярусу середнього карбону, які в ЛВБ відсутні унаслідок посткарбонових розмивів. Водночас слід зазначити, що у межах прикордонної території ЛБ пробурені лише пошукові свердловини, віддалені одна від одної на відстані від 10 до 20 км.

У вугленосній формації прикордонної частини ЛЛБ нараховується від 63 до 90 пластів і прошарків вугілля (в середньому 41-50 пластів) [1]. Відповідно до кондицій, прийнятих для визначення балансових запасів вугілля в Польщі і Україні, в українській частині басейну робочої потужності локально досягають понад 30 пластів, а на польській - п'ять. Сумарна середня потужність вугілля формації змінюється від 7 м в ЛБ 
до 12 м в ЛВБ; загальний коефіцієнт вугленосності - від 1,1 до 1,4 \%, а промисловий - від нульової в ЛБ до $0,5 \%$ в ЛВБ. На 50 м розрізу в ЛБ знаходиться 1,2 пласта, а в ЛВБ - 2,5.

Вугленосність формації змінюється за розрізом. Знизу угору загальна і промислова вугленосність зростає. Однак це відбувається нерівномірно i має циклічний характер. Нижні, рідше середні (регресивні) частини циклів четвертого порядку (мегациклів) характеризуються більш високою вугленосністю, ніж верхні. Це відноситься як до загальної, так і промислової вугленосності. У ЛВБ в нижній частині мегациклів $v_{0}{ }^{3}-\mathrm{V}_{2}, v_{2}-\mathrm{V}_{6}$ розташовуються пласти вугілля $v_{0}{ }^{3}$, $v_{2}$ (Буський), $v_{4}^{2}$ (Бубнівський), які мають робочу потужність на окремих площах. У нижній частині мегациклу $v_{6}-\mathrm{N}_{3}$ знаходиться пласт $v_{6}$. На півдні Червоноградського району він має промислове значення. Найбільш високою вугленосністю характеризується середина четвертого мегациклу $\left(n_{7}-\mathrm{B}_{1}\right)$. До цього інтервалу розрізу приурочені промислові вугільні пласти ЛВБ [1].

Сучасна конфігурація контуру площі поширення промислової вугленосності ЛВБ $\epsilon$ результатом прояву астурийських тектонічних рухів, а також більш пізнього глибокого доверхньоюрського i доверхньокрейдового ерозійного і абразійного зрізів $[5,7]$. ЛВБ займає найбільш піднесену крайову частину Львівсько-Люблінського прогину, де поствугленосні ерозійні процеси відбувалися особливо інтенсивно [1]. Цим пояснюється відсутність у стратиграфічному розрізі відкладів, молодше пізньобашкирських (вестфала А), і дугоподібна форма границі поширення його промислової вугленосності.

Актуальність проведених досліджень полягає у пізнанні загальних процесів формування вугленосних відкладів і продуктивної вугленосності. Викладений матеріал важливий для з'ясування особливостей будови, умов утворення і порівняльного аналізу вугленосних формацій Львівсько-Волинського і Люблінського басейнів.

\section{Література:}

1. Корреляция карбоновых угленосных формаций ЛьвовскоВолынского и Люблинского бассейнов: кол. монографія / В.Ф. Шульга, А. Здановски, Л.Б. Зайцева и др.; отв. ред. А.Я. Радзивилл. Киев: Варта. 2007. 427 c.

2. Kotas A., Porzycky J. Pozycia geologiczna i glowne cechy karbonskich zagleebi weglowych Polski. Prz. Geol. 1984. № 5. S. 125-128.

3. Шульга В.Ф., Вдовенко М.В., Знаменская Т.А. и др. Карбоновые угленосные отложения северного продолжения Большого ЛьвовскоВолынского бассейна. Геол. журн. 1999. № 4. С. 33-44. 
4. Каменные угли Львовско-Волынского бассейна: кол. монографія / Вырвич Г.П., Гигашвили Э.П., Дубик З.Г. и др.; под общ. ред. В.З. Ершова. Львов: Выща шк. при Львов. ун-те. 1978. 175 с.

5. Львовско-Волынский каменноугольный бассейн: Геологопромышленный очерк: кол. монографія / М.И. Струев, В.И. Исаков, В.Б. Шпакова и др.; отв. ред. А.З. Широков. Киев: Наук. Думка. 1984. 272 c.

6. Porzycki J. Tektonika. Karbon Lubelskiego Zagltbia Weglowego. Prace Inst. Geol. 1988. T. 122. S. 9-18.

7. Porzycki J., Zdanowski A. Charakterystyka zlozowa i jakosc wegla. Karbon Lubelskiego Zagltbia Weglowego. Prace Inst. Geol. 1988. T. 122. S. 179-192.

DOI https://doi.org/10.30525/978-9934-26-111-4-43

\section{PROCESSES AND FACTORS CONTROLLING THE GROUNDWATER CHEMISTRY OF THE PLEISTOCENE AQUIFER OF BLACK SEA ARTESIAN BASIN, SOUTH UKRAINE}

\section{Melkonyan D. V.}

PhD (Physics and Mathematics), Associate Professor, Department of Engineering Geology and Hydrogeology

Odesa I. I. Mechnikov National University

\section{Cherkez E. A.}

Doctor of Sciences (Geology and Mineralogy), Professor, Department of Engineering Geology and Hydrogeology

Odesa I. I. Mechnikov National University

\section{Tyuremina V. H.}

PhD (Geology and Mineralogy), Chief geologist

LTD «Gidrogeoservice»

Odesa, Ukraine

Problem Statement and Purpose. In this paper the groundwater chemistry in a Pleistocene aquifer was analyzed to get insight into the factors affecting groundwater quality in a Southern Bug and Syniukha interfluve 